Risvya Faiz Nabila ${ }^{l}$

Melinia Putri Wardani ${ }^{2}$

Meinanda Putri Zalsabella ${ }^{3}$

Wahyuning Pertiwi ${ }^{4}$

Ruina Nur Fitria ${ }^{5}$

Darmadi $^{6}$

\section{RESPON MAHASISWA PENDIDIKAN MATEMATIKA UNIPMA DALAM MEMECAKAN MASALAH GEOMETRI DITINJAU DARI ASPEK FILSAFAT ILMU SELAMA PERKULIAHAN DARING}

\begin{abstract}
Abstrak
Penelitian ini bertujuan untuk mengetahui respon mahasiswa pendidikan matematika dalam menyelesaikan masalah geometri, sehingga dapat mengetahui sejauh mana mahasiswa dapat memahami materi dan menyelesaikan masalah geometri selama perkuliahan daring. Penelitian ini menggunakan metode kualitatif dengan bentuk dan strategi penelitian studi kasus (case study). Dari penelitian ini, diperoleh sebanyak 38 mahasiswa sebagai responden dari semester 2, 4, dan 6 yang mana telah mengikuti pembelajaran mata kuliah geometri secara daring selama pandemi. Kemudian, diambil sebanyak 6 mahasiswa sebagai subjek untuk diwawancarai. Masing-masing subjek tersebut adalah S1, S2, S3, S4, S5, dan S6. Hasil dari penelitian ini yaitu jika dipandang dari aspek epistimologis, mahasiswa merasa bahwa perkuliahan daring kadang-kadang menyenangkan. Sedangkan dari aspek aksiologis, mahasiswa merasa ragu-ragu dalam memahami materi yang disampaikan dan sebagian besar dari mereka juga memiliki kesibukan yang mempengaruhi perkuliahannya, serta materi perkuliahan disampaikan sangat mempengaruhi tugas yang diberikan oleh dosen. Kemudian ditinjau dari aspek ontologi, mahasiswa sudah berada di titik jenuh dengan tugas yang diberikan serta adanya beberapa kendala yang harus mereka hadapi saat perkuliahan daring.
\end{abstract}

Kata Kunci: Pandemi Covid-19, Masalah Geometri, Respon Mahasiswa, Filsafat Pendidikan.

\begin{abstract}
This study aims to determine the response of mathematics education students in solving geometry problems, so that it can find out the extent to which students can understand the material and solve geometry problems during online lectures. This study uses a qualitative method with the form and strategy of case study research (case study). From this research, 38 students were obtained as respondents from semesters 2, 4 and 6 who had participated in online learning of geometry courses during the pandemic. Then, taken 6 students as subject to be interviewed. Each subject is S1, S2, S3, S4, S5, and S6. The result of this research is that if viewed from the epistemological aspect, the students feel that online lectures are sometimes it's fun. Meanwhile, from the axiological aspect, the students feel doubtful in understanding the material presented and most of them also have activities that affect their studies, and the lecture material that delivered greatly affects the assignments that given by the lecturer. Then, viewed from the ontology aspect, the students are already at the saturation point with the given assignments and there are several obstacles they must face during online lectures.
\end{abstract}

Keywords: covid-19 pandemic, geometry problem, student response, educational philosophy.

1,2,3,4,5,6 Program Studi Pendidikan Matematika, Fakultas Keguruan dan Ilmu Pendidikan, Universitas PGRI Madiun

Alamat e-mail : risvya28@gmail.com¹, meliniaputri1426@gmail.com², meinanda.pz@gmail.com³ wahyuningpertiwi02@gmail.com ${ }^{4}$, ruipingky@gmail.com ${ }^{5}$,darmadi.mathedu@unipma.ac.id ${ }^{6}$ 


\section{Pendahuluan}

Dunia dikejutkan dengan mewabahnya suatu penyakit yang disebabkan oleh suatu virus yang bernama coronavirus atau dikenal dengan istilah COVID-19. (Yuliana, 2020) Coronavirus (COVID-19) sendiri tergolong kedalam keluarga virus lama yang menular antar hewan. Pada tahun 30 Januari 2020 WHO telah menetapkan coronavirus sebagai keadaan darurat yang menyebar secara pesat di seluruh belahan dunia. Pembelajaran daring adalah pembelajaran yang mampu mempertemukan siswa dan guru untuk melaksanakan interaksi pembelajaran dengan memanfaatkan internet. Yang mana pembelajaran daring tersebut bertujuan untuk memutus tali penyebaran COVID-19 di Indonesia dan tentu saja untuk kesehatan pelajar itu sendiri. (Fitria \& dkk, 2020). Seluruh sektor kehidupan termasuk dalam dunia pendidikan mengalami kelumpuhan hingga pembelajaran pun dilakukan secara jarak jauh atau daring seperti yang dijelaskan di atas. Sayangnya dalam praktiknya pembelajaran daring tidak semaksimal pembelajaran dikelas, terutama pada pembelajaran matematika. (Fauzy \& Nurfauziah, 2021). (Meinanda, 2020) Matematika dianggap sebagai mata pelajaran yang sulit dan biasanya pembelajaran matematika membutuhkan konsentrasi yang tinggi. Saat ini masih banyak siswa yang kesulitan belajar matematika terutama dalam menyelesaikan soal.

Dalam matematika telah ditemukan beragam penyelesaian masalah yang dikemukakan oleh berbagai ahli. Salah satunya adalah menurut Polya, Polya menemukan langkah-langkah penguraian masalah yang praktis dan tersusun secara lengkap juga sistematis. Langkah pertama dalam penyelesaian masalah matematika menurut (Polya, 1973), yaitu understanding the problem atau memahami masalah. Pada langkah ini, siswa dituntut untuk dapat memahami masalah yang ada dengan cara menentukan apa yang diketahui dan apa yang ada ditanyakan pada masalah tersebut. Langkah kedua yaitu devising a plan atau disebut juga dengan menyusun rencana pemecahan atau penyelesaiannya. Pada langkah ini, mahasiswa perlu mampu dalam menyusun rencana penyelesaian dari masalah yang ada berdasarakan apa yang telah diketahui dan ditanyakan pada masalah sesuai dengan langkah pertama. Langkah ketiga berupa carrying out the plan atau menyelesaikan masalah sesuai dengan perencanaan. Pada langkah ini, mahasiswa dituntut untuk dapat menyelesaiakn permasalahan yang ada sesuai dengan perencanaan yang telah dibuat pada langkah kedua. Langkah keempat yakni looking back atau memeriksa kembali hasil yang telah diperoleh. Pada langkah ini mahasiswa ditekankan untuk memeriksa kembali hasil yang telah diperolehnya dengan tujuan melihat apakah jawabannya sudah benar dan sesuai dengan apa yang ditanyakan pada masalah ataukah belum. Looking back mencerminkan langkah terakhir dalam penyelesaian masalah pada matematika berdasarkan langkah-langkah Polya.

Melalui penelitian secara observasi, sejauh ini diketahui bahwa pembelajaran mata kuliah geometri pada program studi pendidikan matematika Universitas PGRI Madiun menggunakan pendekatan secara konstruktivisme. Pendekatan kontruktivisme berfokus pada tindakan menciptakan suatau makna dari apa yang telah dipelajari. Melalui pendekatan kontruktivisme mahasiswa akan berusaha menemukan solusi dari permasalahan yang dipertanyakan. (Sagala, 2007) menyatakan bahwa dalam pendekatan kontruktivisme pengetahuan dibangun sedikit demi sedikit, kemudian hasil yang diperoleh diperluas melalui konteks yang terbatas (sempit) dan tidak dengan tiba-tiba. Namun, fakta lapangan menunjukan kurang adanya output dari pembelajaran geometri yang difahami secara utuh oleh mahasiswa. Masih jarang dijumpai mahasiswa yang mampu menyelesaikan masalah dengan model yang jauh berbeda dengan yang diajarkan oleh dosen pengampu, sehingga sulit rasanya merealisasikan mahasiswa yang berfikir secara kreatif dan berjiwa ilmuwan dengan mengekplorasi persoalan yang diberikan. 


\section{Penyelesaian Masalah Matematika}

Pembelajaran matematika pada penguasaan indvidual bukanlah penguasaan terhadap matematika sebagai ilmu, melainkan penguasaan akan kecakapan matematika yang diperlukan untuk mampu memahami dunia dan sekitarnya melainkan berhasil dala kehidupan dan karirnya. Di sisi lain tujuan utama akan adanya pembelajaran matematika menurut (Astutiani, Isnarto, \& Hidayah, 2019) adalah mengembangkan kemampuan pemecahan masalah oleh peserta didik. Menurut (o'Brien: 2011:147) menafsirkan masalah secara umum berupa situasi dengan tujuan dan sarana untuk sebagai tujuan yang tidak diketahui sebelumnya, misalnya saja ketika Anda lapar saat larut malam kemudian pergi ke kulkas dan dijumpai kulkas tersebut kosong, maka Anda sedang memiliki masalah. Beliau juga mendefinisikan bahwa pemecahan masalah sebagai keterlibatan dalam suatu tugas yang mana metode penyelesaiannya, peserta didik harus membangkitkan pengetahuan mereka, dan melalui beberapa proses, hingga seiring berjalannya waktu akan menghasilkan pemahaman tentang matematika yang baru. (T.C, O'Brien, \& C, 2011).

Sering kali menjumpai permasalahan baik dalam kehidupan sehari-hari secara langsung maupun dalam dunia pendidikan. Dalam matematika sendiri masalah yang ada biasanya berupa soal matematika, namun tidak menjadikan semua soal dalam matematika merupakan masalah. Untuk meningkatkan skill dalam menyelesaikan masalah perlu adanya pengembangan keterampilan memahami masalah, membuat model matematika, menyelesaikan masalah dan menafsirkan solusi yang ada. Mahasiswa yang terbiasa dalam memecahkan masalah tentunya dapat meningkatkan daya kreatifitas juga sifat cepat tanggap karena terdorong untuk mencari solusi secara cepat dan juga tepat sehingga respon yang diberikan oleh mahasiswa dalam menyelesaikan permasalahan matematika harus mencerminkan kedua aspek tersebut. Sebab apabila masalah diciptakan dan berhubungan dengan kebutuhannya maka mahasiswa akan bersemangat untuk memecahkan masalah matematika dengan relatif singkat. (Omrod, 2008) Menafsirkan bahwa pemecahan masalah adalah menggunakan atau mentransfer pengetahuan dan ketrampilan yang sudah ada untuk menjawab pertanyaan yang belum terjawab atau dalam kondisi lain.

(James, 1976) Mengemukakan bahwa matematika sendiri merupakan ilmu mengenai logika berupa bentuk, susunan, besaran, dan konsep-konsep berhubungan lainnya dengan jumlah yang banyak dan terbagi ke dalam 3 bidang yaitu: aljabar, analisis dan geometri. Geometri menurut (Safrina, 2014) adalah cabang matematika yang diajarkan dengan tujuan agar siswa dapat memahami sifat-sifat dan hubungan antar unsur geometri serta dapat menjadi pemecahan masalah yang baik, sehingga cabang matematika geometri tentunya sangat tepat sebagai media pengukuran aspek kemampuan pemecahan masalah mahasiswa.

(In'am, 2014) Mengungkapkan bahwasannya setiap langkah dalam memecahkan masalah memiliki karakteristik yang berbeda dari satu masalah ke masalah lainnya. Hal tersebut juga terjadi dalam matematika, yang mana pemecahan masalah juga menunjukan karakteristik tertentu dan hal tersebut perlu diketahui sebelum masalah akan dipecahkan. Karakteristik pemecahan masalah dalam matematika berupa, (1) strategi yang tepat diperlukan dalam memecahkan masalah; (2) memiliki pengetahuan penting dalam menghasilkan solusi yang salah; (3) tingkat keterampilan dalam pemecahan masalah yang benar-benar mempengaruhi akurasi dan kesesuian hasil yang diperoleh dalam melakukan pemecahan masalah; (4) pemechan masalah tidak didasarkan pada memori yang dimiliki: (5) setiap masalah memiliki strategi yang unik; (6) berbagai pendekatan harus dipelajari dan dipahami untuk menghasilkan pemecahan masalah yang tepat dan sesuai harapan; (7) pengetahuan keterampian dalam 
menerapkan konsep matematika dan prinsip-prinsip yang telah dipelajari benar-benar membantu untuk memecahkan masalah. (Astutiani, Isnarto, \& Hidayah, 2019)

\section{Geometri}

Geometri merupakan salah satu materi matematika yang telah diajarkan sejak jenjang sekolah dasar. Materi tersebut telah lama dianggap sebagai tempat siswa belajar untuk membuktikan teorema geometris, selain itu geometri juga bertujuan untuk mengajak siswa menganalisa karakteristik bentuk geometris, serta menggunakan visualisasi, penalaran spasial, dan permodelan geometrik untuk menyelesaikan masalah. (NCTM, 2000). Terdapat empat materi dalam geometri yang dijelaskan oleh (Walle) yang meliputi (1) bentuk dan sifat yang mencakup pembelajaran sifat-sifat dari bentuk-bentuk dua dan tiga demensi serta hubungan yang terbangun dari sifat-sifat, (2) transformasi yang mencakup pembelajaran transali, refleksi, rotasi, simetri dan konsep kesebangunan, (3) lokasi yang mengacu pada geometri koordinat atau ara lain dalam menentukan bagaimana benda-benda terletak pada bidang ataupun ruang, (4) visualisasi yang mencakup pengenalan terhadap bentuk-bentuk lingkungan sekitar, menggambarkan dan mengalkan bentuk dari berbagai sudut pandangan.

Geometri menjadi fokus utama dalam penelitian ini sebab materi yang termuat dalam pembelajaran geometri menempati proporsi yang relatif lebih banyak dalam kurikulum tingkatan sekolah reguler. Maka dari itu, geometri dinilai lebih dominan diajarkan kepada siswa, sehingga lebih banyak mencakup aspek kognitif pada dimensi pengetahuan faktual, konseptual dan prosedural.

\section{Respon Mahasiswa}

(Subandi, 1982) Respon dengan istilah umpan balik yang memiliki peran atau pengaruh yang besar dalam menentukan baik atau tidaknya suatu komunikasi. Secara luas respon dapat diartikan dengan suatu reaksi ketika seseorang akan memberikan reaksinya melalui pemikiran, sikap, dan perilaku. Sikap yang ada pada diri seseorang akan memberikan warna pada perilaku atau perbuatan seseorang. Sedangkan secara umum respon atau tanggapan dapat diartikan sebagai hasil atau kesan yang didapat dari sebuah pengamatan.

Menurut Siswoyo $(2007 ; 121)$ mahasiswa dapat didefinisikan sebagai individu yang sedang menuntut ilmu ditingkat perguruan tinggi, baik negeri maupun swasta atau lembaga lain yang setingkat dengan perguruan tinggi. Mahasiswa dinilai memiliki tingkat intelektualitas yang tinggi, kecerdasan dalam berpikir dan kerencanaan dalam bertindak.

Sehingga dapat disimpulkan bahwasannya respon mahasiswa adalah suatu reaksi ketika individu yang sedang menuntut ilmu ditingkat perguruan tinggi akan memberikan reaksinya melalui pemikiran, sikap, dan perilaku.

\section{Filsafat Pendidikan}

Menurut (Amka, 2019) Filsafat pendidikan adalah filsafat yang digunakan dalam studi mengenai masalah-masalah pendidikan. Filsafat dalam pendidikan memberikan inspirasi bagaimana mengorganisasikan proses pembelajaran yang ideal. Filsafat pendidikan mendasari pemikiran tentang kebijakan dan prinsip-prinsip pendidikan. Filsafat sendiri memiliki 3 cabang, yaitu (1) Menurut (Kristiawan, 2016) Ontologi termasuk dalam bahasan metafisika umum. Onotologi membahas tentang "ada". Pertanyaan yang diajukan:apa yang dimaksud dengan ada, keberadaan atau eksistensi itu. (2) Epistemologi mempersoalkan kebenaran pengetahuan. Epistemologi berasal dari Bahasa Yunani yaitu episteme $=$ pengetahuan dan logos $=$ teori. Epistemologi dapat didefinisikan sebagai cabang filsafat yang mempelajari asal mula atau sumber, struktur, dan metode yang sah tentang pengetahuan. Persoalan-persoalan dalam 
epistomologi adalah : Bagaimana manusia dapat mengetahui sesuatu?; Dari mana pengetahuan itu diperoleh?; Bagaimana validitas pengetahuan itu dapat dinilai. (3) Aksiologi adalah cabang filsafat yang mempersoalkan penilaian atau yang berhubungan dengan nilai guna (manfaat).

Oleh karena itu, perlu adanya penelitian lebih lanjut untuk mengetahui respon mahasiswa pendidikan matematika dalam menyelesaikan masalah geometri. Sehingga, dapat mengetahui sejauh mana mahasiswa dapat memahami materi dan menyelesaikan masalah geometri.

\section{METODE}

Penelitian ini menggunakan metode kualitatif dengan bentuk dan strategi penelitian studi kasus (case study), yaitu penelitian difokuskan pada satu fenomena saja yang dipilih dan dipahami secara mendalam, dengan mengabaikan fenomena-fenomena lainnya. Pada penelitian ini mencari tahu respon mahasiswa dalam menyelesaikan masalah geometri berdasarkan 3 aspek filsafat ditinjau dari rasa sangat senang, senang, tidak senang, sangat tidak senang dan bagaimana cara mahasiswa dalam menyelesaikan permasalahan geometri.

Penelitian ini dilakukan di Universitas PGRI Madiun pada bulan Mei sampai dengan Juni 2021 mulai tahap persiapan hingga penulisan laporan penelitian dengan jumlah responden sebanyak 38 mahasiswa, dimana mahasiswa pendidikan matematika Universitas PGRI Madiun dijadikan sebagai subjek penelitian. Peneliti menentukan subyek penelitian dengan menggunakan sampel bertujuan (purposive sample). Menurut Moleong (2013:224), sampel bertujuan dipilih bukan untuk memusatkan diri pada adanya perbedaan-perbedaan yang nantinya dikembangkan ke generalisasi, tetapi untuk merinci kekhususan yang ada dan untuk menggali informasi yang akan menjadi dasar rancangan dan teori yang muncul. Selain itu, pemilihan subjek dilakukan dengan pertimbangan antara lain : (1) Subjek penelitian merupakan mahasiswa pendidikan matematika; (2) Subjek penelitian berasal dari tingkat semester yang berbeda sehingga proses pemahaman dan penyelesaian berbeda pula; (3) Subjek penelitian berasal dari mahasiswa yang memiliki tingkat kebahagiaan yang berbeda.

Penelitian ini diawali dengan pengisian angket melalui google form oleh 42 mahasiswa pendidikan matematika tahun akademik 2020/2021 untuk mengkategorikan mahasiswa yang merasa sangat senang, senang, tidak senang, sangat tidak senang, yang kemudian akan diambil sebanyak 6 mahasiswa sebagai sampel untuk diwawancarai. Masing-masing sampel tersebut yaitu S1, S2, S3, S4, S5, S6. Data hasil penelitian ini merupakan respon mahasiswa dalam menyelesaikan masalah geometri yang diperoleh dari transkrip wawancara. Hasil transkrip tersebut berupa percakapan peneliti dan subjek yang selanjutnya direduksi untuk memperoleh data terkait respon siswa berdasarkan 3 aspek filsafat yaitu ontologi, epistomologi, dan aksiologi.

Dalam hal ini peneliti sudah menyiapkan pertanyaan yang akan diajukan dalam wawancara bersama responden, dan wawancara dilakukan di tempat yang nyaman sesuai keinginan responden yang bersangkutan. Semua informasi yang didapat sudah mendapatkan persetujuan dari responden. Dan pertanyaan yang diajukan tidak menyinggung pihak lain maupun mengandung SARA.

1. P1: Bagaimana kesan Anda terkait perkuliahan daring/online?

2. P2: Apakah pada saat perkuliahan daring berlangsung, Anda dapat memahami materi perkuliahan yang disampaikan oleh dosen dengan baik?

3. P3: Apakah Anda memiliki kesibukan tertentu yang mungkin mempengaruhi perkuliahan Anda?

4. P4: Perkuliahan daring mempengaruhi tugas yang diberikan oleh dosen. 
5. P5: Apakah tugas yang diberikan oleh dosen di perkuliahan daring ini terlalu berlebihan sehingga terkesan memberatkan mahasiswa?

6. P6: Apakah Anda setuju jika perkuliahan secara online/daring lebih menyenangkan daripada kuliah offline/tatap muka?

\section{HASIL DAN PEMBAHASAN}

Dalam penelitian ini, kami membagikan formulir tentang pelaksanaan kuliah daring. Dalam formulir tersebut diperoleh 38 responden dari mahasiswa Pendidikan Matematika Universitas PGRI Madiun dengan 5 responden dari semester 2, 20 responden dari semester 4, 8 responden dari semester 8 dan 5 responden dari semester 8 . Berikut adalah presentase dari responden:

Tabel 1. Presentase Responden

\begin{tabular}{|c|c|c|c|c|c|c|}
\hline No. & $\mathbf{P}$ & \multicolumn{5}{|c|}{ Presentase Responden } \\
\hline \multirow[t]{2}{*}{1.} & \multirow[t]{2}{*}{$\mathrm{P} 1$} & $\begin{array}{c}\text { Sangat } \\
\text { menyenangkan }\end{array}$ & Menyenangkan & $\begin{array}{l}\text { Kadang-kadang } \\
\text { menyenangkan }\end{array}$ & \multicolumn{2}{|c|}{$\begin{array}{c}\text { Sangat tidak } \\
\text { menyenangkan }\end{array}$} \\
\hline & & $2,6 \%$ & $13,2 \%$ & $71,1 \%$ & \multicolumn{2}{|c|}{$2,6 \%$} \\
\hline \multirow[t]{2}{*}{2.} & $\mathrm{P} 2$ & Sangat paham & Paham & Ragu-ragu & $\begin{array}{l}\text { Tidak } \\
\text { paham }\end{array}$ & $\begin{array}{c}\text { Sangat } \\
\text { tidak } \\
\text { paham }\end{array}$ \\
\hline & & $0 \%$ & $10,5 \%$ & $81,6 \%$ & $5,3 \%$ & $2,6 \%$ \\
\hline \multirow[t]{2}{*}{3.} & \multirow[t]{2}{*}{ P3 } & \multicolumn{2}{|c|}{ Iya } & Mungkin & \multicolumn{2}{|c|}{ Tidak } \\
\hline & & \multicolumn{2}{|c|}{$39,5 \%$} & $31,6 \%$ & \multicolumn{2}{|c|}{$28,9 \%$} \\
\hline \multirow[t]{2}{*}{4.} & \multirow[t]{2}{*}{$\mathrm{P} 4$} & $\begin{array}{c}\text { Sangat } \\
\text { mempengaruhi }\end{array}$ & Mempengaruhi & $\begin{array}{l}\text { Kadang-kadang } \\
\text { mempengaruhi }\end{array}$ & $\begin{array}{c}\text { Tidak } \\
\text { mempengar } \\
\text { uhi }\end{array}$ & $\begin{array}{c}\text { Sangat } \\
\text { tidak } \\
\text { mempeng } \\
\text { aruhi }\end{array}$ \\
\hline & & $39,5 \%$ & $31,6 \%$ & $26,3 \%$ & $2,6 \%$ & $0 \%$ \\
\hline \multirow[t]{2}{*}{5.} & \multirow[t]{2}{*}{ P5 } & Sangat setuju & Setuju & Ragu-ragu & $\begin{array}{l}\text { Tidak } \\
\text { setuju }\end{array}$ & $\begin{array}{l}\text { Sangat } \\
\text { tidak } \\
\text { setuju }\end{array}$ \\
\hline & & $5,3 \%$ & $39,5 \%$ & $39,5 \%$ & $13,2 \%$ & $2,6 \%$ \\
\hline \multirow[t]{2}{*}{6.} & \multirow[t]{2}{*}{ P6 } & Sangat setuju & Setuju & Ragu-ragu & $\begin{array}{l}\text { Tidak } \\
\text { setuju }\end{array}$ & $\begin{array}{l}\text { Sangat } \\
\text { tidak } \\
\text { setuju }\end{array}$ \\
\hline & & $2,6 \%$ & $13,2 \%$ & $34,2 \%$ & $39,5 \%$ & $10,5 \%$ \\
\hline
\end{tabular}

Keterangan:

P : Pertanyaan

Berdasarkan jawaban pada formulir tersebut, kebanyakan merasa perkuliahan daring kadang-kadang menyenangkan. Maka dari itu mereka merasa perkuliahan secara daring tidak lebih menyenangkan daripada kuliah tatap muka. Dalam hal ini perasaan para responden tersebut masuk ke dalam cabang filsafat epistimologi, tentang perasaan senang dan tidak senang. Sebagian besar para responden merasa ragu-ragu dalam memahami materi yang disampaikan dan sebagian besar dari mereka juga memiliki kesibukan yang mempengaruhi perkuliahannya serta Perkuliahan yang disampaikan sangat mempengaruhi tugas yang diberikan oleh dosen. Hal tersebut masuk ke dalam cabang filsafat aksiologi, tentang pemahaman terhadap materi serta yang terpengaruh dari pemahaman materi tersebut. Banyak dari para responden merasakan bahwa tugas yang diberikan terlalu berlebihan dan memberatkan. Para responden 
juga menyebutkan beberapa kendala yang mereka hadapi selama mengikuti perkuliahan daring di antaranya adalah kurangnya kuota internet, kurang memahami penggunaan aplikasi matematika, kesulitan mendapatkan akses internet, kesulitan memahami materi yang diberikan karena tidak bertatap langsung dengan dosen, sudah jenuh dengan metode yang diberikan saat perkuliahan daring. Metode perkuliahan yang sering digunakan saat perkuliahan daring oleh dosen dari para responden adalah dengan memberikan pertanyaan atau latihan soal untuk diselesaikan. Perasaan memberatkan dari tugas yang diberikan, kendala saat perkuliahan daring, perasaan jenuh masuk ke dalam cabang filsafat ontologi tentang alasan dari perasaan senang dan tidak senang terhadap perkuliahan daring

Berkaitan dengan pemecahan masalah dalam menyelesaikan latihan soal khususnya materi geometri kami melakukan wawancara terhadap 6 subjek mahasiswa Pendidikan Matematika Universitas PGRI Madiun di antaranya subjek 1 dari semester 1, subjek 2 sampai subjek 4 dari semester 4, subjek 5 dan 6 dari semester 6 . Berikut adalah hasil dari wawancara terhadap 6 subjek pada 2 indikator:

Tabel 2. Hasil Wawancara Indikator Pemahaman Materi Geometri

\begin{tabular}{|l|l|c|c|c|c|c|c|}
\hline No. & Indikator Pemahaman Materi & S1 & S2 & S3 & S4 & S5 & S6 \\
\hline 1. & Memahami materi & $\sqrt{ }$ & $\sqrt{ }$ & $\sqrt{ }$ & $\sqrt{ }$ & $\sqrt{ }$ & $\sqrt{ }$ \\
\hline 2. & Mencari materi pendukung (Internet/Buku) & $\sqrt{ }$ & $\sqrt{ }$ & $\sqrt{ }$ & $\times$ & $\sqrt{ }$ & $\times$ \\
\hline 3. & Mencari video pendukung & $\sqrt{ }$ & $\sqrt{ }$ & $\sqrt{ }$ & $\times$ & $\times$ & $\times$ \\
\hline 4. & Memahami contoh soal & $\sqrt{ }$ & $\sqrt{ }$ & $\sqrt{ }$ & $\times$ & $\times$ & $\sqrt{ }$ \\
\hline 5. & Mencari contoh soal yang serupa dan mempelajarinya & $\times$ & $\times$ & $\sqrt{ }$ & $\sqrt{ }$ & $\sqrt{ }$ & $\times$ \\
\hline 6. & $\begin{array}{l}\text { Menyelesaikan masalah sesuai dengan materi yang } \\
\text { sudah dipahami }\end{array}$ & $\sqrt{ }$ & $\sqrt{ }$ & $\sqrt{ }$ & $\sqrt{ }$ & $\sqrt{ }$ & $\sqrt{ }$ \\
\hline 7. & $\begin{array}{l}\text { Menyelesaikan masalah lain yang serupa dengan } \\
\text { tingkatan lebih tinggi }\end{array}$ & $\times$ & $\times$ & $\sqrt{ }$ & $\sqrt{ }$ & $\sqrt{ }$ & $\times$ \\
\hline 8. & Evaluasi & $\sqrt{ }$ & $\times$ & $\times$ & $\sqrt{ }$ & $\times$ & $\times$ \\
\hline
\end{tabular}

Tabel 3. Hasil Wawancara Indikator Pemecahan Masalah Geometri

\begin{tabular}{|l|l|c|c|c|c|c|c|}
\hline No. & Indikator Pemecahan Masalah & S1 & S2 & S3 & S4 & S5 & S6 \\
\hline 1. & Memahami masalah & $\sqrt{ }$ & $\sqrt{ }$ & $\sqrt{ }$ & $\sqrt{ }$ & $\sqrt{ }$ & $\sqrt{ }$ \\
\hline 2. & Mencari materi pendukung (Internet/Buku) & $\sqrt{ }$ & $\sqrt{ }$ & $\sqrt{ }$ & $\times$ & $\sqrt{ }$ & $\times$ \\
\hline 3. & Mencari video pendukung & $\sqrt{ }$ & $\sqrt{ }$ & $\sqrt{ }$ & $\times$ & $\times$ & $\times$ \\
\hline 4. & Menyusun rencana penyelesaian & $\sqrt{ }$ & $\times$ & $\sqrt{ }$ & $\sqrt{ }$ & $\times$ & $\sqrt{ }$ \\
\hline 5. & $\begin{array}{l}\text { Menyelesaikan sendiri dengan bantuan video/materi } \\
\text { pendukung }\end{array}$ & $\times$ & $\times$ & $\times$ & $\times$ & $\sqrt{ }$ & $\sqrt{ }$ \\
\hline 6. & Menyelesaikan dengan aplikasi & $\times$ & $\times$ & $\sqrt{ }$ & $\sqrt{ }$ & $\sqrt{ }$ & $\times$ \\
\hline 7. & Menyelesaikan dengan browsing & $\sqrt{ }$ & $\times$ & $\sqrt{ }$ & $\sqrt{ }$ & $\sqrt{ }$ & $\times$ \\
\hline 8. & Menyelesaikan masalah sesuai dengan rencana & $\sqrt{ }$ & $\times$ & $\sqrt{ }$ & $\times$ & $\times$ & $\sqrt{ }$ \\
\hline 9. & Kendala yang dihadapi dan cara menyikapinya & $\sqrt{ }$ & $\sqrt{ }$ & $\sqrt{ }$ & $\sqrt{ }$ & $\sqrt{ }$ & $\sqrt{ }$ \\
\hline 10. & Memeriksa kembali & $\sqrt{ }$ & $\times$ & $\sqrt{ }$ & $\sqrt{ }$ & $\times$ & $\times$ \\
\hline
\end{tabular}

Keterangan:

1. $\sqrt{ }:$ Memenuhi

2. $\times$ : Tidak Memenuhi 
Berdasarkan hasil wawancara terhadap 2 indikator tersebut, semua subjek dapat memahami materi geometri dengan baik. Jika merasa kesulitan dalam memahami materi mereka akan bertanya kepada teman, mencari contoh soal, mempelajari materi yang diberikan oleh dosen, mempelajari catatan yang dimiliki, mencari referensi materi dari internet. Begitupun dengan memecahkan permasalahan soal geometri, selain itu ada beberapa dari subjek yang di wawancarai juga menggunakan aplikasi untuk menyelesaikan soal. Seperti yang disampaikan oleh subjek 6, aplikasi yang sering digunakan untuk menyelesaikan masalah geometri adalah wolfram dan geogebra. Penggunaan aplikasi tersebut masuk ke dalam cabang filsafat aksiologi tentang penggunaan aplikasi. Dalam penyelesaiannya semua subjek memiliki beberapa kendala seperti yang diungkapkan oleh subjek 2 dan subjek 3. Subjek 2 mengatakan kendala yang sering dialami adalah kurang mampu untuk berpikir lebih luas dan menghubungkan suatu masalah dengan konsep-konsep yang sudah diketahui, misalnya untuk melakukan sebuah pembuktian dari suatu masalah terkadang masih cenderung bingung untuk menentukan mana postulat atau teorema yang bisa menjadi pembuktian untuk masalah tersebut. Sedangkan subjek 3 mengatakan sering lupa dengan konsep yang dipelajari.

\section{SIMPULAN}

Pembelajaran daring masih akan terus dilakukan di Indonesia mengingat belum ada peraturan secara resmi mengenai pembelajaran luring dari Pemerintah. Namun, praktiknya pembelajaran daring tidak semaksimal pembelajaran di kelas terutama pada pembelajaran matematika yang mana juga memerlukan pemahaman konsep dalam pemecahan masalah. Salah satunya pada pembelajaran mata kuliah geometri di Perguruan Tinggi. Mahasiswa perlu pemahaman dalam proses pemecahan masalah pada mata kuliah geometri yang mana di dalamnya terdapat teori-teori pembuktian konsep yang terstruktur melalui tahapan-tahapan penyelesaian masalah, sehingga dibutuhkan ketelitian dan kepahaman akan konsep materi yang dipelajari. Dari penelitian yang telah dilakukan dapat dikatakan bahwa perkuliahan daring selama pandemi COVID-19 dipandang dari aspek utama filsafat ilmu yaitu mahasiswa merasa perkuliahan daring kadang-kadang menyenangkan berdasarkan aspek epistimologis, sedangkan ditinjau dari aspek aksiologis mahasiswa merasa ragu-ragu dalam memahami materi yang disampaikan dan sebagian besar dari mereka juga memiliki kesibukan yang mempengaruhi perkuliahannya serta perkuliahan yang disampaikan sangat mempengaruhi tugas yang diberikan oleh dosen, kemudian ditinjau dari aspek ontologi mahasiswa sudah berada di titik jenuh dengan tugas yang diberikan dan kendala yang mereka hadapi saat perkuliahan daring.

\section{DAFTAR PUSTAKA}

Amka. (2019). Filsafat Pendidikan. Sidoarjo: Nizama Learning Center.

Astutiani, R., Isnarto, \& Hidayah, I. (2019). Kemampuan Pemecahan Masalah Matematika dalam Menyelesaikan Soal Cerita Berdasarkan Langkah Polya. Seminar Nasional Pascasarjana, 1-3.

Fauzy, A., \& Nurfauziah, P. (2021). Kesulitan Pembelajaran Daring Matematika Pada Masa Pandemi COVID-. Jurnal Cendekian: Jurnal Pendidikan Matematika, Vol. 05, No.01, 551-561.

Fitria, R. N., \& dkk. (2020). Tingkat keaktifan siswa dalam pembelajaran matematika menggunakan e-learninh dan platform daring. Jurnal Review Pendidikan dan Pengajaran, vol.3 No. $2: 306$.

In'am, A. (2014). The Implementation of the Polya Method in Solving Euclidean Geometry Problems. International Education Studies, Vol. 7 No.7: 150.

James, V. j. (1976). mathematic dictionary. nostrand: rienhold.

Kristiawan, M. (2016). Filsafat Pendidikan;The Choice Is Yours. Jogjakarta: Valia Pustaka 
Meinanda, dkk. (2020). Dampak Pembelajaran Jarak Jauh Terhadap Perasaan Tertekan Pada Siswa Kelas Tujuh SMP Saat Memahami Konsep Matematika. Jurnal Review Pendidikan dan Pengajaran, 294-298.

Moleong, L. (2012). Metodologi Penelitian Kualitatif. Bandung: PT. Remaja Rosdakarya.

NCTM. (2000). Principles, Standards, and Expectations. Retrieved from. Diambil kembali dari https://www.nctm.org/Standards-and-Positions/Principles-and-Standards/Principles,-Standards,-

Omrod, J. E. (2008). Psikologi Pendidikan (Membantu Siswa Tumbuh dan Berkembang). Jakarta: Penerjemah: Amitya Kumara : Erlangga.

Polya, G. (1973). How To Slove It (A New Aspect of Mathematics Method). New Jersey: Priceton University Press.

Safrina, K. (2014). Peningkatan Kemampuan Pemecahan Masalah Geometri Melalui Pembelajaran Kooperatif Berbasis Teori Van Hiele. Jurnal Didaktik Matematika, vol. 1(1) 9-20.

Salistiyani, Usodo, B., \& Pramudya, I. (2016, November). Respon Siswa dalam Memecahkan Masalah Matematika pada Materi Geometri Berdasarkan Taksonomi SOLO Ditinjau dari Tingkat Metakognisi Siswa Kelas X SMA Negeri 1 Cepu. Jurnal Elektronik Pembelajaran Matematika, 4, 802-811.

Subandi, A. (1982). Psikologi Sosial. Jakarta: Bulan Bintang.

T.C, W., O'Brien, \& C, M.-D. (2011). Problem Based Learning in Mathematics. The mathematic enthusiast. Vol. 8 No. 1\&2: 147-160.

Van De Walle, J. (2015). Pengembangan Pengajaran Matematika Sekolah Dasar dan Menengah . Jakarta: Erlangga.

Wiramihardja. (2007). Pengantar Filsafat. Bandung: Refika Aditama.

Yuliana. (2020). Corona Virus Diseases . Wellnes And Healthy Magazine , 187-192. 